\author{
TARJA-LIISA HYPÉN \\ Tf. lektor i finländsk litteratur, fakulteten för spräk, \\ översättning och litteratur, Tammerfors universitet
}

\title{
KÄNDISFÖRFATTARENS VARUMÄRKE I FINLAND
}

\begin{abstract}
THE BRAND OF THE CELEBRITY AUTHOR IN FINLAND | In the $21^{\text {st }}$ century, the celebrity author has begun to interest researchers not only as a marketing phenomenon, but also as the literary institution's own phenomenon. In my article, I explore the relationship of the celebrity author to the so-called acclaimed authors of modern times. In Anglo-American research, the celebrity author and the bestselling author are distinguished as separate author types, but in the case of Finnish Jari Tervo, these types combine. For almost 20 years, Jari Tervo has been among both the most sold and the most visible celebrity authors in his home country. I examine how the publicity and brand of the Finnish celebrity author are formed. I consider how the brand affects the author's works on the one hand, and the reception of the works on the other. I point out the limiting effects of the brand, but I also examine how, in combining the high and the low,

it affords mobility in the literary fields while it also offers an opportunity to influence society.
\end{abstract}

KEYWORDS | celebrity author, bestseller, brand, authorship, Jari Tervo.

Kändisförfattare är en av de synligaste delarna av den litterära institutionen i dagens samhälle. I och med att de litterära kändisarnas kommersiella betydelse och synlighet $\mathrm{i}$ offentligheten har vuxit allt mer ökar också deras kulturella betydelse. Därför finns det orsak att undersöka kändisförfattarna även ur andra perspektiv än som marknadsfenomen, och under 20oo-talet har man börjat dryfta deras ställning och funktion inom den litterära institutionen. Forskningen kring kändisförfattare är ännu så ny och ringa till sin omfattning, och närmar sig sitt objekt från så olika synvinklar, att begreppet kändisförfattare inte entydigt kan sammanfattas utifrån den internationella forskningen. Tills vidare kan man utifrån forskningsresultaten endast sammanställa vissa element som kan ingå i en definition: författarens anseende och hur känd författaren är, mångsidig synlighet för författarens person $\mathrm{i}$ media ${ }^{\mathrm{I}}$ och författarnamnets karaktär av varumärke (Boorstin 57; Ponce de Leon 4; Moran 6; English och Frow 4I, 44; Wernick 93-94). Dessutom har begreppet

I En egen kategori av kändisförfattare utgör de i vilkas varumärken det centrala innehållet är att de håller på sig undan offentligheten: deras osynlighet skapar i sig riklig uppmärksamhet i media. De kändaste exemplen är J. D. Salinger och Thomas Pynchon (Boorstin I03; Moran 54). Bland dagens finländska författare representerar bestsellerförfattaren Ilkka Remes bäst denna typ. Inte ens på stora litteraturmarknader kan det däremot på en gång finnas alltför många författare som tar en sådan undanskymd roll, då förlorar metoden sin effekt. 
kändisförfattare hållits i sär från begreppet bestsellerförfattare (exempelvis Moran 6). Varken stilen eller genren för författarens produktion har i forskningen under 200o-talet lyfts fram som faktorer som definierar kändisförfattaren. Vilken författarbild representerar denna typ av författare? Hur mycket och med vilka medel kan författaren själv påverka sin image? Vad innebär det att en författare blir ett varumärke, ett "brand"? Hur inverkar författarens framgångar på hans eller hennes produktion och på verkens innehåll?

Jag granskar dessa frågor genom att som exempel använda Jari Tervo (f. 1959), en finländsk författare vars verk har legat i toppen på den inhemska försäljningsstatistiken i I5 år och som samtidigt torde vara den författare vars ansikte är allra kändast för mannen på gatan i Finland. Exempelfallet illustrerar de nationella särdragen i fenomenet kändisförfattare eftersom definitionen av kändisförfattare förmodligen påverkas av i vilken litterär kultur och på en hur stor litterär marknad författaren är verksam. Behandlingen bygger emellertid på den internationella forskningen och bland de centrala frågor forskningen lyfter fram tar jag först upp de faktorer som inverkar på hur författaren skapar sin image, sedan relationen mellan bestseller- och kändisförfattarskap och till slut varumärket som en kraft som definierar författarens person och produktion, och som styr receptionen. Jag gör också jämförelser med internationellt kända författare som J. K. Rowling, Salman Rushdie och mer detaljerat Paul Auster.

\section{Författarens rykte och personliga marknadsföring}

John Rodden som har forskat i författarens rykte definierar rykte som en kulturell relation där alla deltar. Ryktet utgör den kumulativa följden av oräkneliga instanser av reception, acceptans och avståndstagande (Rodden 66). Författaren kan alltså inte själv besluta om sitt rykte eller sin image utan de uppstår med tiden i receptionen. En författares rykte handlar bland annat om vilka associationer han eller hon väcker bland publiken (87). Även om en författare inte själv kan besluta om sitt rykte är det fullt möjligt för författaren att bidra med element som författarens image byggs upp av. Jari Tervo visade redan i början av sin karriär en exceptionell vilja såväl att få publicitet som att påverka publicitetens art. Inträdet på litteraturens område kräver emellertid också utomstående hjälp. Tervo vann en kulturtävling för studerande och en av domarna $i$ tävlingsjuryn sände, utan Tervos vetskap, de vinnande dikterna till ett förlag som visade intresse för dem. Resultatet var att två insatta och omfattande recensioner av debutsamlingen publicerades, båda i viktiga litterära tidskrifter.

Den andra diktsamlingen som utkom 1983 väckte däremot ingen offentlig uppmärksamhet. Ett dylikt förbigående är inte i sig ovanligt, men Tervo nöjde sig inte med den tystnad som lade sig kring verket. Han skrev själv en recension av sin diktsamling. Den egenhändiga recensionen (Tervo, "Uhoilua" 4) lyfter fram centrala teman i samlingen, men är till sin stil en parodi på en mördande kritik - Tervo har alltid varit redo att ta till självironi för att få publicitet. Då Tervo år 1984 började 
jobba som journalist på en kvällstidning såg han till att han syntes i huvudstadens journalist- och kändiskretsar. Det första personreportaget om honom skrevs 1985 i Ylioppilaslehti (Studentbladet). I intervjun avslöjar Tervo ärligt sin publicitetsstrategi: "Om det finns minsta möjlighet att jag genom att väsnas på krogen eller göra mig till åtlöje i Ilta-Sanomat ${ }^{2}$ kan få fram min poesi eller prosa, så är det bara bra" (Saarikoski 3).

Redan i sin första personintervju kunde Tervo utnyttja en strategi för att skapa en så kallad dramatisk verklighet. Den dramatiska verkligheten är en berättelse som antingen framhäver dramatiska inslag i personens verkliga liv, eller blandar det som verkligen skett med det uppdiktade (Rein et al. I23). Undersökningen High Visibility som för fram personlig marknadsföring som medel räknar upp följande mål för den dramatiska verkligheten: Den fångar publikens uppmärksamhet och stimulerar deras fantasi. Den stärker den marknadsförda personens trovärdighet och höjer intresset för personen. Vidare skapar den hos publiken en föreställning om att den har en relation till personen. (Ibid.) Redan i sin första intervju lanserade Jari Tervo en av sina berättelser som bidrar till att bygga upp hans dramatiska verklighet: På kvällen efter sin studentfest hade han, berusad, beslutat simma över den strida Kemi älv. Polis, brandkår och ambulans hade tillkallats för att rädda honom från att drunkna. Tervo stannade däremot inte i sin hemstad Rovaniemi i Lappland för att utreda det skedda, utan reste redan följande morgon till Helsingfors för att inleda sina universitetsstudier. Denna berättelse har under de senaste decennierna upprepats otaliga gånger i intervjuer med Tervo. Eftersom Tervo enligt de som kände honom var en tyst mönsterelev under sin skoltid är det endast incidenten med älvsimningen som från den tiden stöder bilden av en bohemisk poet. Att återberätta historien stärkte därför trovärdigheten i hans tidigaste roll.

I tidningsintervjuer med Tervo och i personreportage om honom återkommer också åtskilliga andra anekdoter som bygger upp den dramatiska verkligheten. Anekdoter är en av de vanligaste metoderna för att skapa en dramatisk verklighet, och för personlig marknadsföring i allmänhet. Särskilt då man talar om en författare utgör anekdoter bevis på att författaren har uppnått ett ansenligt rykte (Rodden 9I). Som författare är Jari Tervo känd som en humoristisk och skicklig berättare. Det bereder honom inga svårigheter att mata offentligheten med skojiga anekdoter om sig själv. Med sin långa erfarenhet av journalistiskt arbete kan han också vara till hjälp för dem som skriver om honom: intervjuaren behöver inte ensam anstränga sig för att producera en intressant artikel, Tervo kan erbjuda färdiga och noggrant uttänkta ingredienser för den. Då en läsare som följer Tervo i en tidningstext stöter på episoder och anekdoter ur Tervos liv som läsaren känner till sedan tidigare från andra sammanhang upplever läsaren sig läsa om en gammal bekant. I den personliga marknadsföringen av en framgångsrik författare måste man sikta just på denna selektiva bekantskap. Då man har forskat i J. K. Rowlings,

2 Ilta-Sanomat är den största kvällstidningen i Finland. Tervo arbetade på heltid som redaktör på tidningen åren I984-1995. 
världens hittills mest framgångsrika författares, karriärstrategi har man observerat att en av de centrala faktorerna i den är författarens selektiva familjaritet: publiken ska uppleva författaren som en bekant samtidigt som författaren noga skyddar sitt privatliv och presenterar enskilda element i sin offentliga gestalt enligt en utarbetad plan och efter noggrann sållning (Rein et al. 176).

Utgivningen av debutromanen Pobjan hovi år I990 var en av vändpunkterna i receptionen av Tervo. I kritiken av de fyra diktsamlingar som föregått romanen hade Tervos synliga journalistarbete ofta använts som utgångspunkt för utvärderingen, men av recensionerna att döma vann debutromanen sin publik även utan stöd av Tervos person. Verkets tema, en tragikomiskt belyst grupp av män i Lappland, upplevdes fräsch och den personliga, omsorgsfullt uppbyggda berättartekniken väckte förtjusning. Romanen Pohjan hovi kan anses vara ett av de bästa, kanske rentav det bästa, verket i Tervos produktion, där det 23:e verket utkom på hösten 20II. En annan etapp som innebar att Tervo togs ett snäpp mer på allvar som författare var romanen Pybiesi ybteyteen från I995. Romanen var en av finalkandidaterna för Finlandiapriset och missade priset med knapp marginal.

De finländska förlagen och undervisningsministeriet instiftade tillsammans Finlandiapriset 1984, och priset har såväl kulturella som marknadsmässiga mål. Den som väljer pristagaren är oftast en offentlig person, exempelvis presidentens äkta hälft, och alltså inte nödvändigtvis en expert som hör till den litterära institutionen. De verk som når finalen väljs däremot av en jury som består av experter på litteratur eller kultur i en vidare bemärkelse. De väljer finalisterna bland kandidater som förlagen lägger fram som urval av de romaner som publicerats under det gångna året. Därför är det med tanke på författarens anseende viktigare att vara finalkandidat än att vinna priset. Redan kandidaturen garanterar stor publicitet och mycket god försäljning.

Den viktigaste etappen i Tervos offentliga karriär hittills är emellertid tv-showen Uutisvuoto (Snacka om nyheter i Sverige), ett underhållningsprogram som kombinerar frågesport och dagspolitisk satir, och som har sänts sedan I998. Att författaren uppträder i en talkshow på tv har konstaterats vara ett av de effektivaste sätten att marknadsföra en bok (Moran 37; Sutherland, Reading the Decades I63). Uutisvuoto är sedan I4 år ett av de mest sedda underhållningsprogrammen i Finland och Tervo har inte bara gästat showen utan varit en av panelens två permanenta medlemmar. I programmet hänvisas ändå sällan till Tervos roll som författare. De år Tervo har varit kandidat för Finlandiapriset, I999 och 2004, var hans kandidatur föremål för lättare skämt i showen, så länge man väntade på den slutliga prisutdelningen. På detta sätt fick man tv-tittarna att hålla tummarna för Tervo och på sätt och vis ställa sig bakom "sin egen" kandidat, mot de övriga kandidaterna. Även om man på detta sätt marknadsför Tervos verk är den egentliga marknadsförda produkten mer omfattande - det handlar om ett varumärke. 


\section{Författaren som varumärke}

Enligt allmän uppfattning definierades "ett brand" första gången då American Marketing Association år 1960 slog fast att det innebär "ett definierande namn och eller en symbol (såsom en logo, ett varumärke eller utformningen av en förpackning), vars syfte är att identifiera antingen en säljares eller grupp av säljares varor eller tjänster och att avgränsa dessa varor eller tjänster från konkurrenternas motsvarande" (cit. enligt Bengtsson I8).

Ett författarnamn kan fungera på exakt samma sätt som ett varumärke: det identifierar produkten (författarens verk) och garanterar produktens kvalitet för köparna. Varumärket fungerar som en fast punkt till vilken kvalitativa faktorer kan kopplas semiotiskt, genom reklam och marknadsföring. Kvalitet är däremot mer symboliskt då man talar om en författare och om skönlitteratur, än då det gäller marknadsföringen av varor i allmänhet (Wernick 93-94).

John Rodden anser att ett av de viktigaste tecknen på en författares anseende är att samma epitet, "identifierande ord", upprepas i samband med författarens namn (Rodden 87, 9I). Etablerade epitet avslöjar också det väsentliga innehållet i författarens varumärke: även om de inte alltid på ett träffande sätt beskriver författarens produktion beskriver de träffande den allmänna föreställningen om författaren. Utom att de uttrycker varumärket bidrar de till att skapa och upprätthålla det. Bland de identifierande ord Tervo som förknippas med är "fyndighet" det som oftast upprepas i kritiken av hans verk. Fyndigheten kommer till uttryck i den prisade verbalismen, i berättartekniska lekar med strukturer, i en mångbottnad komik och $\mathrm{i}$ intrigerna som byggs upp av serier av överraskningar. De identifierande orden dök upp redan i kritiken av Tervos första diktsamling. Redan då berömdes den språkliga virtuositeten, bland annat dikternas färska metaforer, liksom komiken, som kom till uttryck bland annat i uppfinningsrika ordlekar. Ända sedan den första kritiken har emellertid de identifierande orden varit tveeggade: samtidigt som språket fick beröm höjdes varningar för att konstra till språket för mycket. Medan komiken noterades med godkännande konstaterades det att den låg riskabelt nära lättsamt raljerande.

Släkt med de identifierande orden är de mer omfattande summeringarna av produktionens natur. Då Tervo inledde sin prosaproduktion stämplade kritikerna honom som en skildrare av människor som lever i marginalen i Lappland, särskilt som skildrare av män ur ett maskulint perspektiv, en skapare av tragikomiska personer och situationer, den groteska världens målare. De identifierande orden hängde med i recensionerna: Tervos romanfigurer var verbala konstnärer, verken var skojiga och senast som slutlig kulmen på intrigen kunde man vänta sig en överraskning som ställer allting på huvudet. Recensenterna såg envist på verken ur dessa etablerade utgångspunkter, även då en noggrannare läsning hade förändrat bilden. Novellsamlingen Taksirengin rakkaus från 1998 fick exempelvis kritikerna att beskylla Tervo för att hans figurer åter var "klonade motormunnar". Ändå utgör den längsta novellen i samlingen - en text om en taxichaufför, nästan lika 
omfattande som en kortroman - ett diskursförsök där idén uttryckligen är den att huvudpersonen inte säger ett ord.

I början av sin karriär skötte Tervo själv sin personliga marknadsföring med hjälp av alla tillgängliga metoder. Då den tredje diktsamlingen kom ut (I988) ansåg förlaget redan att Tervos person fungerade som en marknadsföringstrumf. Som omslagsbild på samlingen använde man en serie bilder på Tervos ansikte - man hade knappast fastnat för en sådan lösning om det hade handlat om en upphovsman som var okänd för allmänheten. Senare, på den andra romanen Poliisin poika (1993), beslutade man använda författarnamnet närmast som en logo: en "Jari Tervo"-logo tryckt i kraftiga färger och med ojämna konturer dominerade pärmen och såg konkret ut som ett brännmärke, ett "brand". Denna pärmlogo återanvändes sedan från verk till verk, som om den stämplats i samma form, ända till slutet av I990-talet. Med sin kraftiga färgsättning påminde pärmarna även i övrigt om varandra, och bidrog till att verken uppfattades som en serie.

Det budskap pärmarna och namnlogon förmedlade var: häftigt, maskulint, groteskt. Visst fanns också dessa ingredienser i verken; den som köpte ett av verken kunde lita på varumärket. Köparen kunde vänta sig en skojig, spännande och fyndig bok som av läsaren kräver förmågan att tolerera groteska bilder och uttryck. Samtidigt fanns det också skillnader mellan verken och egenskaper som i den offentliga receptionen har överskuggats av varumärkets kännetecken. Stilen varierar från slingrande medvetandeström till ett kryptiskt avskalat uttryck. Vid sidan av männen som lever i marginalen dök också medelklassen samt kvinnor, barn och äldre upp som föremål för beskrivningarna. Särskilt i receptionen av Minun sukuni tarina kom seriemässigheten och varumärket att bli ett fängsel som inte ens kritikerna förstod att bryta: romanens centrala tematik noterades aldrig.

Celia Lury definierar ett varumärke i kulturproduktionen på följande sätt: "att producera ett varumärke innebär en process där kulturprodukten formas för att fungera som sin egen reklam, eller för att skapa en publik för sig själv" (Lury 207). Det har ända från början varit Jari Tervos öppna syfte att sälja så mycket som möjligt. Målet har alltså varit att nå en så bred publik som möjligt, och detta mål har han uppnått. Jari Tervos senaste verk har varit ett enkelt val då någon letat efter en gåva till en vanlig (medelålders) finländare (man). Kritikerna har stött varumärket väl. Om en recension för ett ögonblick har gått in på verkets berättartekniska finesser har den genast i följande stycke kunnat lugna Tervos förmodade läsare med att verket nog kan läsas ledigt och avspänt av vem som helst. Debutromanen Pohjan hovi var enligt en kritiker så skickligt utformad att den till och med utgjorde en alltför artistisk helhet. De senare verken har inte väckt liknande omdömen eftersom det inte har ansetts nödvändigt att fokusera på en estetisk bedömning, i skuggan av varumärket. Såväl kritiker som förlaget har undvikit att nämna Tervos postmodernism, vilket är en iögonenfallande brist särskilt i marknadsföringen och receptionen av Minun sukuni tarina. Det är ändå mycket förståeligt med tanke på varumärket. Mannen på gatan som utgör Tervos förmodade publik hade knappast på 1980- och I990-talet uppfattat postmodernism som en lockande egenskap vid valet av läsning. 
Helsingin Sanomat (den största dagstidningen i Finland) har använt uppfinningsrika metoder för att främja försäljningen av Tervos verk: år 200I publicerade tidningen i sin veckobilaga en serie recensioner från andra tidningar av Tervos senaste roman (Harju 8-IO). Poängen bakom artikeln var att romanen faktiskt ännu inte hade kommit ut, för att inte tala om recensioner av den. I artikeln varierades kritikens diskurs enligt i vilken typ av tidning den sades ha blivit publicerad. Den underhållande artikeln kan antas ha fäst uppmärksamhet vid den nya romanen på samma sätt som förhandsreklam gör. Intressant nog byggdes de fiktiva recensionerna helt upp av delelement ur Tervos varumärke och av sådana epitet och identifierande ord han förknippas med - om själva romanen och dess karakteristiska drag avslöjade de ingenting. Man kunde tänka sig att artikeln i Helsingin Sanomat hade presenterat en utmaning för de som verkligen recenserade romanen. De verkliga recensionerna påminde emellertid i mycket hög grad om de fiktiva. Detta bevisar konkret att ett enskilt verk inte rubbar ens professionella läsares förtroende för ett starkt varumärke.

James F. English och John Frow har påpekat att författaren som varumärke aldrig är uteslutande en kommersiell modell, utan att det snarare handlar om en omsorgsfull hantering av författarens person som fortsätter att uppfattas som en värdekälla (English och Frow 52). Tervos gestalt i slutet av I990-talet var ett exempel på en lyckad hantering av författarens person: gestalten var "fyllig" (se Rein et al. 2II) på ett sätt som även tillät konflikter. Endast på ett område föreföll det som om Tervo hade fastnat i en roll som verkade permanent och vars gränser var svåra att bryta. Akademisk uppskattning och en plats i kanon verkade det mer än tjugo år långa författarskapet inte ge, av en enkel orsak: Jari Tervo är en kändisförfattare.

\section{Kändisförfattaren}

"En kändis är en person som är känd för att vara känd”, sammanfattade Daniel J. Boorstin minnesvärt i sitt klassiska verk om kändisforskning The Image (57). Senare kändisforskning har försökt lösgöra sig från detta påstående och dess nedsättande karaktär. Man har exempelvis framhävt att kändisfenomenet är en följdriktig produkt av moderniseringen av det västerländska samhället. Charles L. Ponce de Leon sätter kändisfenomenet i samband med moderniteten och kopplar in det som en del av utvidgningen av marknadsekonomin, demokratins tillväxt och de individualistiska värdenas segertåg. Kändisen skulle vara den vackraste blomman som dessa av Ponce de Leon sammankopplade utvecklingsprocesser ger upphov till, inte alls en "grotesk mutation i en för övrigt frisk organism". (Ponce de Leon 4). Han argumenterar så pass logiskt att det borde övertyga anhängare av den västerländska kapitalismens värden. Om man i en frisk organism i alla fall upptäcker något att förbättra bör kändisfenomenet snarare hyllas än avvisas. Ponce de Leons slutsatser kan däremot inte övertyga anhängare av andra värderingar att se kändisfenomenet som någonting positivt, i stället erbjuder de bara en klart formulerad grund för en negativ attityd till fenomenet. 
I den nyaste forskningen om kändisförfattarskap behandlas litterära kändisar inte som onödiga enligt Boorstins modell, men de hyllas inte heller utifrån de utgångspunkter Ponce de Leon erbjuder. Joe Moran konstaterar i sin undersökning Star Authors (2000) att kändisfenomenet är föränderligt och mångfasetterat. Det utgör resultatet av invecklade förhandlingar mellan kulturproducenterna och deras publik. Kändisfenomenet är en förmedlare av såväl dominerande kulturella som motkulturella betydelser. Det kan med framgång utnyttjas för att granska förhållandet mellan kulturell auktoritet och bytesvärde i det kapitalistiska samhället. Utöver att kändisfenomenet $i$ och för sig har den karaktär som beskrivs ovan skiljer sig kändisförfattarskapet enligt Moran dessutom väsentligt från det kändisfenomen som produceras av kommersiella massmedia. Fenomenet kändisförfattare uppstår enligt Moran inte direkt ur den process där kultur förvandlas till handelsvara, utan lyfter fram viktiga frågor om förhållandet mellan litteratur och marknad, och mellan högt och lågt. Med hänvisning till Pierre Bourdieu konstaterar Moran att fenomenet skiljer sig från ekonomiska fenomen genom att det i dess centrum står en individ som besitter särskilda gåvor och kvalitetsrelaterade förtjänster. (Moran 3-4, 5). Enligt James F. English och John Frow är däremot kändisförfattarskapet snarare ett medie- och marknadsföringsfenomen än ett fenomen från litteraturens område. Även de poängterar emellertid att fenomenet kändisförfattare inte helt och hållet är en produkt av det kommersiella maskineriet: författarna själva strävar både genom sina texter och genom sina medieframträdanden efter att forma kändisfenomenets funktion och undvika vissa av dess vanliga effekter. (English och Frow 4I, 44).

Även om fenomenet kändisförfattare är typiskt för dagens kultur påminner English och Frow oss om att det har en lång historia. Som exempel på fenomenet inom den brittiska litteraturen nämner de redan från I700-talet bland annat Samuel Johnson och Laurence Stern, från I8oo-talet Lord Byron, Charles Dickens och Oscar Wilde. (English och Frow 40). Om man liksom John Rodden skiljer på berömda författare och kändisförfattare på den grund att endast de först nämnda blir kända för sin litterära produktion (Rodden 57) blir exemplen på kändisförfattare på I700- och I80o-talen däremot tvivelaktiga. Kanske skillnaden mellan de två typerna inte är så skarp som Rodden hävdar: berömmelse som härstammar från uppskattning för verken kan i receptionen ha fått drag av kändisfenomen redan på I700- och I80o-talet; publicitetens former och medel avviker bara från dagens. Rykte skapar rykte, som även Rodden konstaterar - samtidigt kan formerna för att upprätthålla ryktet vara kopplade också till annat än produktionen. Under en tid då det inte var möjligt att uttrycka eller skapa kändisförfattarskap genom tv och tidningsbilder kunde man i stället exempelvis resa en staty över en litterär kändis på en central plats, så att den breda allmänheten fick möjlighet att se den.

Joe Moran skiljer mellan bestsellerförfattare och kändisförfattare på följande sätt: Även om bestsellerförfattare är berömda även som personer är de snarare författare som läses, inte författare man läser om. Kändisförfattarna däremot är de som intervjuas och diskuteras i media, som vinner priser, vars verk studeras på 
universiteten och som uppträder som gäster i talk shower. (Moran 6). Föremål för Morans forskning är den amerikanska nutidslitteraturen och det amerikanska litterära systemet. Tillämpat på finländska kändisförfattare kan man bland kännetecknen utan tvekan utelämna det att författarens verk studeras på universiteten; i Finland är gränsen mellan högt och lågt skarpare än i USA. I Finland kan visserligen en akademiskt respekterad författare också med tiden bli en kändisförfattare, men bara för att bli kändisförfattare behöver man inte (och får man inte) stöd av forskarna. ${ }^{3}$

En bestseller definieras i allmänhet som ett verk som säljer mer än andra under en given tidsperiod (Niemi I3; se även Sutherland, Bestsellers 5-6, II, 3I). Att en upphovsman får in sina verk på bestsellerlistorna är inte gynnsamt för den litterära uppskattningen. Den akademiska diskussionen har inte traditionellt letat efter sina objekt bland högarna av bestseller. John Sutherland som har forskat i bestsellern som fenomen har hävdat att orsaken till detta är enkel: försäljningsframgångarna döljer sällan tilldragande skönlitterära värden. Bestsellern besitter inte en textens "okränkbarhet”, och upplevs inte ens som ett fullbordat verk med ett egenvärde. Den betraktas som en del av det kommersiella maskineriet, som en gren i det produktions- och konsumtionsmaskineri vars övriga grenar är publicitet, författarens image och publikens behov. Enligt Sutherland är bestseller intressanta som forskningsobjekt av andra orsaker än estetiska: som informationskällor om sin egen tids bokförsäljning och bokmarknad, om den läsande publiken och samhället mer allmänt. (Bestsellers 4-5). Även om bestsellerfenomenet fortfarande kan undersökas på de sätt som Sutherland nämner, som stöd för litteratursociologiska och kulturvetenskapliga utredningar, har forskarna sedermera observerat att de kan ha funktionella karakteristika även ur en skönlitterär synvinkel.

I finländsk skala kan man tala om Jari Tervo som en bestsellerförfattare ungefär från år I995 då hans första Finlandia-kandidatur klart påverkade försäljningen också av de tidigare verken, så mycket att de sedan dess kontinuerligt har tryckts i nya upplagor. Under 200o-talet har Tervos romaner, totalt åtta till antalet, klart överskridit bestseller-gränsen som i Finland är cirka Io ooo sålda exemplar (Niemi I3). Mest har romanen Myyrä sålt (7I 300 exemplar under utgivningsåret 2004), men även de övriga har under månaderna omedelbart efter utgivningen sålt klart över bestseller-gränsen: 27 800-57 300 exemplar (Finlands Förlagsförening rf:s statistik). Redan debutromanen sålde bra och efter den har förlaget, som nämnts, presenterat verken som en serie med enhetliga pärmar och författarnamnet tryckt på ett logoaktigt sätt. Det är exakt så man agerar på bestsellermarknaden. Redan verkets yttre signalerar att det som erbjuds inte bara är en författares nyaste verk, Jari Tervos nyaste roman, utan en produkt, den nyaste "jari tervo" (se Sutherland, Bestsellers II9).

3 Då detta skrivs har inte en enda vetenskaplig artikel eller undersökning publicerats om Jari Tervo, en av de mest offentliga författarna i Finland. 


\section{Varumärkets gränser och kändisförfattarens makt}

En sådan "nyaste jari tervo" var också romanen Minun sukuni tarina från I999, tack vare de ovan nämnda metoderna för marknadsföring. En av de centrala gestalterna i romanen är en brottsling från Norra Finland, en av intrigerna handlar om att reda ut en komplicerad serie brott och den för Tervo typiska "verbalismen" tar sig denna gång uttryck i växlingar mellan olika typer av diskurs. De här aspekterna av romanen motsvarar väl de förväntningar Tervos varumärke väcker. Verkets centrala tematik har däremot ingenting att göra med elementen i Tervos varumärke, temat är i stället varumärket $\mathrm{i}$ sig. I centrum för romanen står frågor om olika typer av texter och om vilket slags texter som i Finland i slutet av 1990-talet upplevdes som skönlitteratur värd uppskattning. Romanen utforskar de villkor under vilka litteratur produceras i dagens Finland, och parodierar med bitande självironi just den typ av författare Tervo själv representerar.

Enligt Joe Moran har kändisförfattare ofta ett behov av att även i sin produktion genom autobiografi och autofiktion behandla sin ställning och publicitetens effekter. Han anser att detta egentligen inte är ett tecken på en "narcissismens kultur" utan snarare handlar om en process som är nödvändig för kändisförfattaren. Texter av den här typen fungerar som en kanal för att bearbeta kändisfenomenet och den oro som kändisförfattare enligt Moran ofta känner för att bibehålla sitt upphovsmannaskap. (Moran 69-70). Moran har forskat i amerikanska kändisförfattares självreflexiva verk och upptäcker i deras inställning till kändisförfattarens situation dels antipati, dels godkännande, dels blindhet för de egna omständigheterna, dels sakkunskapen hos en som ser fenomenet inifrån (I49). Det är ändå rätt svårt att bedöma Jari Tervos Minun sukuni tarina på den axel mellan antipati och godkännande som Moran erbjuder, eftersom romanen är starkt parodisk. Däremot är det enklare att bedöma dess sakkunskap.

Sakkunskapen i Tervos verk kommer fram i att det på ett mångfasetterat sätt behandlar villkoren för författarskapet. Romanens berättare, författaren $\mathrm{T}$, sprattlar i ett nät av motstridiga inflytanden, förlagets krav, marknadsföringens lagar, belöningssystem, de förväntningar den litterära traditionen ställer, enskilda läsares smak och fördomar mot författarens arbete, familjens och släktens behov samt framför allt mediernas makt. Tervo reflekterar i sin roman inte uteslutande över sin egen ställning utan avslöjar hela den litterära institutionens verksamhet. Ett blint område finns det ändå $\mathrm{i}$ avslöjandet. Romanen ger en mycket traditionell och för publiken bekant bild av förlaget. Samarbetet mellan författaren och förlagsredaktören, om vilket man i Tervos eget fall vet att det är mycket nära, har lämnats utanför behandlingen. Här följer Tervo ett tyst avtal som råder i förlagsvärlden: om naturen hos och innehållet i författarens och förlagets arbetsrelation avslöjar man ingenting för utomstående (Svedjedal II3).

Minun sukuni tarina för tankarna till den avslutande delen i Paul Austers New York-trilogi The Locked Room (I986). I den, liksom i Tervos verk, smälter två författares liv samman med varandra, och i båda romanernas värld slutar det verkliga 
mästerverket i den mindre geniala men mer publicitetskunniga författarens namn. I båda romanerna är det bara den mindre begåvade författaren som lever reellt och på den litterära institutionens villkor, den verkliga talangen försvinner i ett mytiskt dunkel, han finns egentligen inte. Skillnaden mellan verken är att det i Tervos roman finns fler skikt och dimensioner och en rejäl dos humor, någonting som helt saknas hos Auster. En annan skillnad är att Austers verk blev en världssuccé. Tervos roman blev visserligen också en succé, i Finland. Den nominerades som kandidat för Finlandiapriset, även om den inte fick själva priset denna gång. I stället premierades den med Finlands Deckarförenings pris för årets bästa detektivroman - ett pris som inte riktigt gör verkets natur rättvisa. Receptionen av Minun sukuni tarina är på sätt och vis ett bra exempel på att genren inte kan anses ha förhindrat den litterära eliten att uppskatta Tervos verk. Den litterära eliten har inte stiftat bekantskap med verkets genre eftersom en onyanserad förhandsuppfattning som författarens varumärke bidragit till har utgjort ett hinder i sig: Minun sukuni tarina har definierats som en deckare trots att den kan anses vara en detektivroman i första hand endast om också Paul Austers The Locked Room primärt kan ses som en detektivroman - i båda romanerna är detektivintrigen underställd den övriga tematiken.

En tredje skillnad mellan Tervos och Austers romaner är att Austers verk blev en världssuccé särskilt som en ikon för den postmoderna litteraturen, vilket den också marknadsfördes som; i marknadsföringen av Tervos verk nämndes däremot ingenting om postmodernism. Minun sukuni tarina är ändå postmodernistisk särskilt i sin mångfasetterade metafiktivitet, i sin sönderklippta struktur, i sammanblandningen av olika tidsplan och i sin lek med identiteter. Den blandar åtskilliga olika texttyper, allt från en biedermeieraktig brevstil till efterbildningar av barns tal, ungdomsslang, krönikestil, dagboksprosa och tidningsspråk och ända till lyrik. Då han till slut inkluderar till och med chifferkod kan verket inte bara anses vara postmodernistiskt utan också misstänkas vara en parodi på postmodernismen.

Kändisförfattaren förvandlas till en bild, en fritt flytande betydelsebärare i kulturen (Coombe IOI; Moran 6I). Därför kan författaren inte till fullo kontrollera sitt varumärke (Wernick 95) eller användningen av sin image (Moran 6I). Dessutom kan kändisfenomenet vara skadligt för författarskapet på flera olika sätt (English och Frow 40), redan därför att det finns en risk för att vilken som helst produkts varumärke dessutom kan utgöra ett hinder för konsumtion (Bengtsson I9). Då en författares verk på basis av varumärket uppfattas följa en viss modell låter en del läsare bli att skaffa eller läsa dem, just för att varumärket inte intresserar dem.

Även om positionen som kändisförfattare har garanterat bestsellerstatus för Jari Tervos alla verk i mer än I5 år har varumärket inskränkt författarbilden av honom och stått i vägen för akademiskt erkännande. Romanen Myyrä från 2004 förefaller vara ett klart försök att förändra varumärket.

Den historiska spionthrillern beskrev president Kekkonen och Finlands historia från och med första världskriget, men fokuserade främst på en moralisk utvärdering av den efterkrigstida perioden, den så kallade finlandiseringsperioden. Tervo 
hade valt en ny kurs som i den finländska litteraturhistorien alltid har visat sig välfungerande med tanke på författarens anseende. De romaner som i Finland har visat sig ha ett bestående värde har ofta behandlat brytningspunkter i nationens samtidshistoria och ventilerat nationella trauman (Niemi 44, 86).4

Tervo skrev på romanen Myyrä i fyra år och läste cirka 20 ooo sidor politisk historia som underlag för sitt arbete. Då romanen kom ut väckte den enorm uppmärksamhet i medierna och nominerades för Finlandiapriset (men vann inte). Tervo själv åkte på turné i Finland och talade inför välfyllda salar om sin historietolkning. Kritiken var huvudsakligen positiv. Kritikerna konstaterade att Tervo äntligen hade lämnat skildringen av de kriminella kretsarna i Lappland bakom sig och börjat skriva om något "vettigt". En del recensenter noterade emellertid att många element i Tervos varumärke ändå fanns kvar. Detta var naturligtvis nödvändigt för att varumärket inte skulle vara i fara. Men målet var samtidigt att göra varumärket mångsidigare. Receptionen gav också grönt ljus för att Tervo kunde fortsätta i den valda riktningen utan att varumärket blev lidande. De två romaner som följde på Myyrä kompletterade granskningen av samtidshistorien och tillsammans utgjorde romanerna en trilogi. Till försäljningsframgångarna bidrog vidare att seriens första och sista del behandlade gestalter vars historiska förebilder är i allra högsta grad offentliga i Finland: president Kekkonen och marskalk Mannerheim. Den mellersta romanen i serien hade inget sådant dragplåster och även om försäljningen klart överskred bestseller-gränsen var den lägre än för de två andra delarna. Av kritiken att döma påverkade och förändrade redan trilogins inledande del Myyrä Tervos varumärke: i största delen av de mer än sextio publicerade tidningsrecensionerna behandlades verket som en historisk roman med ett viktigt tema, inte som en spionthriller, även om intrigens nivå gjorde det möjligt att genrebestämma verket även på detta sätt. Exempelvis i Helsingin Sanomats recension karakteriserades romanen som ett "dramatiskt epos över det självständiga Finlands politiska historia" (Kantokorpi C2), och enligt den respekterade tidskriften Suomen Kuvalebti var Myyrä "det mest betydande verket i Tervos produktion hittills och en lysande närhistorisk roman” (Hämäläinen 38).

Bilden av en seriös författare fick sig en liten törn i och med romanen Koljatti från 2009. Denna dagspolitiska satir är den av Tervos bestseller som tydligast uppvisar de egenskaper hos en bestseller som den angloamerikanska forskningen har påvisat. Särskilt kvällstidningarna försökte skapa uppståndelse kring verket genom att dag efter dag följa hur verkets verkliga förebilder reagerade på romanen, genom att provocera feministiska forskare att hetsa upp sig över verkets kvinnobild och till slut genom att påstå att författaren själv hade blivit upprörd över receptionen av boken. I artiklarna kom det visserligen fram att ingen av de provocerade själv

4 Det viktigaste exemplet är Väinö Linna och hans romanserie Här under polstjärnan I-III (I959-I962) som beskriver den politiska och sociala historien i Finland under 190o-talet, samt framförallt hans roman Okänd soldat (1954) som beskriver den finska fronten under andra världskriget. Okänd soldat är en nationell ikon vars filmversion visas på tv varje år på självständighetsdagen och som alla finska barn läser i skolan. 
hade medgett sig ha blivit upprörd, men löpsedlarna sålde såväl tidningar som flera exemplar av verket. Romanen Koljatti gjordes härmed till just det som Boorstin definierar som en bestseller: den är ett verk som är känt för att vara känt (Boorstin IO3).

Att bara ett verk i Tervos omfattande produktion verkligen uppfyller de angloamerikanska kännetecknen på en bestseller säger något om den finländska författartypens särart: författartypen kan utmärkt förena egenskaper som förknippas med såväl en bestsellerförfattare som en kändisförfattare. Den finländska frågan är huruvida man till denna kombination ännu kan foga den litterära elitens uppskattning. För de amerikanska författare som Joe Moran har forskat i är det möjligt. Moran konstaterar att kändisförfattare i USA i allt högre grad utgör potentiella deltagare på den kulturella produktionens hela fält: såväl på den sida där myten om det individuella geniet är som starkast, som på den marknadsdrivna sidan där denna myt har ansetts vara svagast. Kändisförfattarna har en sammanförande ställning i den litterära produktionen; just de kan förena högt och lågt. (Moran 6-7). English och Frow konstaterar det samma; enligt dem förenar kändisförfattarskapet två olika principer: å ena sidan den linje som bygger på romantikens myt och som utgår från upphovsmannens underskrift och från upphovsrätten, där man vill uppleva upphovsmannen som autentisk och personligen närvarande, å andra sidan den industrialiserade, varumärkesstyrda, kvalitetskontrollerade och serieartade litteraturens linje (English och Frow 5I).

Det är intressant at dryfta situationen i det litterära systemet i Finland mot en bakgrund av Hans Hertels modell av litteraturens fem kretslopp. Hertel delar upp litteraturen i cirklar som räknat inifrån är: det speciallitterära, det populärlitterära, det masslitterära, det intermediala och det orala kretsloppet. Genom ett stort antal exempel illustrerar Hertel att kretsloppen förenas av en "mediehiss" som kan lyfta ett verk från ett kretslopp till ett annat, både inåt och utåt. (Hertel 207-2II). Modellen beskriver säkert verkens öden även i Finland, men helt friktionsfritt förefaller inte hissen löpa i alla lägen. Som Hertel konstaterar blev det redan på I970-talet klart att Robert Escarpits bipolära modell som endast separerar höglitteratur och populärlitteratur fungerar dåligt för att beskriva det skandinaviska litterära livet (207). Trots detta kunde den traditionella tudelningen lämpa sig för att beskriva en viss styvhet i den finländska receptionen, som jag har illustrerat med Tervo som exempel. I Escarpits modell finns det mellan det två polerna ett gemensamt område, det vill säga det finns verk för vilka det är möjligt att bryta blockaden (ibid.). Enligt den nyaste forskningen kring kändisförfattare kunde just en författare som Tervo med sin produktion höra till blockadbrytarna (jmf. Moran 5I; English och Frow 53), men i Finland förefaller detta inte ha skett tills vidare - författarens image och särskilt varumärket som förenar författaren och produktionen utgör ett hinder.

Det är svårt för en finländsk kändisförfattare att bryta sitt varumärke så att hans eller hennes verk exempelvis kunde fungera på olika sätt för olika läsargrupper, redan då de utkommer. Det är möjligt att Sofi Oksanen kan lyckas bättre 
med detta än Tervo. Tack vare sin personlighet som är fascinerande för media blev Oksanen en av Finlands synligaste kändisförfattare redan innan hennes tredje roman Utrensning (2008) nådde så fenomenala framgångar. Oksanens bestsellerroman Utrensning påminner om Tervos historiska romaner även så tillvida att den är ett verk med en spännande intrig och beskriver ett närhistoriskt trauma. Oksanen har emellertid med sin roman vunnit såväl de viktigaste finländska litterära priserna som betydande utländska priser (Nordiska rådets litteraturpris 20IO, The European Book Prize 20Io, Le Prix du Roman Fnac 20I0), och översättningsrättigheterna för romanen har hittills sålts till 4I språkområden. Framgångarna i utlandet kunde tänkas väcka akademiskt intresse även i Finland. Så kommer det däremot inte nödvändigtvis att bli, vilket receptionen av satirikern Arto Paasilinna har visat. Paasilinnas produktion har översatts till nästan 50 språk och han är inte bara populär utan också respekterad i länderna i Mellaneuropa, framförallt i Frankrike. I Finland har Paasilinna visserligen i decennier varit en bestsellerförfattare och kändis som intresserar kvällspressen, men hans produktion har inte väckt allvarligt intresse exempelvis bland forskare.

Enligt John Sutherland kunde en bestseller vara ett kraftigt instrument för samhällelig förändring, men han tillägger att det är sällan en sådan funktion förverkligas. Som ett av de få exemplen nämner han Harriet Beecher Stowes Uncle Tom's Cabin. (Bestsellers 246). Joe Morans exempel är färskare: Toni Morrison som har lyft fram frågor om ras och kön samt Cornel West och Henry Louis Gates som har behandlat samma teman (Moran 5I). English och Frow nämner å sin sida det kändaste exemplet av alla, Salman Rushdie, som har blivit den synligaste förespråkaren för det "svarta Britanniens" kultur (English och Frow 53). Direkt, samhällelig påverkan med skönlitteraturens medel har emellertid saknats ur Tervos program som kändisförfattare. Den saknas inte längre: hans roman Layla som utkom i september 201 berättar historien om en kurdisk kvinna som hamnar i Finland som prostituerad. Romanen tar ställning mot de så kallade "invandrarkritiska" tankegångarna och rasismen som är på frammarsch även i Finland. Jari Tervo har alltså hittills på ett lyckat sätt utnyttjat de möjligheter som har varit tillgängliga för den författartyp han representerar, enligt resultaten från den internationella forskningen kring kändisförfattare. I det finländska litterära systemet har det varit möjligt för honom att kombinera kändisförfattarens och bestsellerförfattarens roller. Kunde han i framtiden med sin produktion avvika från kändisförfattarens normala rutter och tillföra denna typ något nytt? Ur ett finländskt perspektiv är det också intressant att få se om han lyckas erövra en plats bland de respekterade författarna utan att förlora de fördelar det ger att representera en annan typ av författare. 


\section{LITTERATURLISTE}

Auster, Paul. The Locked Room. The New York Trilogy. London: Faber, 1987.

Bengtsson, Anders. Consumers and Mixed-Brands. On the Polysemy of Brand Meaning. Lund Studies in

Economics and Management 70. Lund: Lund Business Press, 2002.

Boorstin, Daniel J. The Image. A Guide to Pseudo-Events in America. New York: Atheneum, I977.

Coombe, Rosemary J. "Author/izing the Celebrity. Publicity Rights, Postmodern Politics, and

Unauthorised Genders." The Construction of Authorship. Textual Appropriation in Law and Literature.

Red. Martha Woodmansee och Peter Jaszi. Durham: Duke University Press, I994: IOI-I3I.

English, James F. och Frow, John. "Literary Authorship and Celebrity Culture.” A Concise Companion

to Contemporary British Fiction. Red. James F. English. Oxford: Blackwell, 2006: 39-57.

Harju Hannu. "Se on mestariteos!” Helsingin Sanomat. Viikkoliite Nyt. 33 (200I): 8-Io.

Hertel, Hans. "Boken i mediesymbiosens tid.” Litteratursociologi. Texter om litteratur och sambälle. Red.

Lars Furuland och Svedjedal, Johan. Lund: Studentlitteratur, I997: 202-222.

Hämäläinen, Karo. “Suomettuneisuuden kulisseissa.” Suomen Kuvalehti. 38 (2004): 38.

Kantokorpi, Mervi. "Kuka kusee yhteiseen keittoon?” Helsingin Sanomat. 29. augusti 2004: C2.

Linna, Väinö. Okänd soldat (Tuntematon sotilas i orig.). II-I3 udg. Borgå: WSOY, I955 [I954].

Linna, Väinö. Här under polstjärnan (Tä̈llä Pobjantähden alla i orig.). Borgå, Helsingfors, Juva: WSOY, I987 [1959-I962].

Lury, Celia. Cultural Rights. Technology, legality and personality. London, New York: Routledge, I993.

Moran, Joe. Star Authors. Literary Celebrity in America. London: Pluto Press, 2000.

Niemi, Juhani. Suomalaisten suosikkikirjat (De populäraste böckerna i Finland). Hämeenlinna: Karisto, I997.

Oksanen, Sofi. Pubdistus. Helsinki: WSOY, 2008.

Ponce de Leon, Charles L. Self-Exposure. Human-Interest Journalism and the Emergence of Celebrity in America, I890-I940. Chapel Hill: University of North Carolina Press, 2002.

Rein, Irving; Kotler, Philip; Hamlin, Michael och Stoller, Martin. High Visibility. The Making and Marketing of Professionals into Celebrities. 3. udg. New York: McGraw-Hill, 2005.

Rodden, John. The Politics of Literary Reputation. The Making and Claiming of 'St. George' Orwell. Oxford: Oxford University Press, I989.

Saarikoski, Saska. "Laiha ja hiljainen poika". Ylioppilaslehti. 2 (I985): 3.

Finlands Förlagsförening rf:s statistik. I6. september 201 .

〈http://www.kustantajat.fi/tilastot/bestsellerit/default.aspx $>$.

Sutherland, John. Bestsellers. Popular fiction of the I970s. London: Routledge and Kegan Paul, I98I. Sutherland, John. Reading the Decades. Fifty Years of the Nation's bestselling Books. London: BBC, 2002.

Svedjedal, Johan. The Literary Web. Literature and Publishing in the Age of Digital Production. A Study in the Sociology of Literature. Stockholm: Kungliga Bibilioteket, 2000.

Tervo, Jari. Koljatti. Romaani. Helsinki: WSOY, 2009.

Tervo, Jari. Layla. Helsinki: WSOY, $20 I I$.

Tervo, Jari. Minun sukuni tarina. Porvoo, Helsinki, Juva: WSOY, I999.

Tervo, Jari. Myyrä. Romaani. Helsinki: WSOY, 2004.

Tervo, Jari. Pohjan hovi. Porvoo, Helsinki, Juva: WSOY, 1992.

Tervo, Jari. Poliisin poika. Helsinki: WSOY, I993. 
Tervo, Jari. Pyhiesi yhteyteen. Romaani. Porvoo, Helsinki, Juva: WSOY, I995.

Tervo, Jari. Taksirengin rakkaus. Porvoo, Helsinki, Juva: WSOY, I998.

Tervo, Jari. “Uhoilua ja unteluutta.” Ylioppilaslebti. I9 (I983): I4.

Wernick, Andrew. "Authorship and the supplement of promotion. "What is an author?” Red. Maurice Biriotti och Nicola Miller. Manchester: Manchester University Press, I993, 85-IO3. 